Politik Indonesia: Indonesian Political Science Review 1 (1) (2016) 14-29

Politik Indonesia

Indonesian Political Science Review

http://journal.unnes.ac.id/nju/index.php/JPI

\title{
Jean-Jaques Rousseau dalam Demokrasi
}

Daya Negri Wijaya ${ }^{1 凶}$

${ }^{1}$ Universitas Negeri Malang, Indonesia

\section{Info Artikel}

Sejarah Artikel:

Diterima 15 Juli 2015

Disetujui 15 Desember 2015

Dipublikasi 15 Januari 2016

Keywords:

Philosophy of Politics;

General will; Civil Society;

Ethics of Politics

\section{Abstrak}

JJ Rousseau adalah salah satu pemikir politik. Dia hidup sejalan dengan majunya ilmu pengetahuan dan seni. Namun, dia merasa dengan adanya kemajuan semakin menggerus moralitas masyarakat. Demokrasi menurutnya diterapkan secara langsung tanpa ada perwakilan dari rakyat. Hal ini disebabkan karena kebebasan setiap warga negara harus diperjuangkan. Setiap orang memiliki hak alamiah yang tidak bisa direbut dan diberikan pada orang lain. Mereka menjalin kesepakatan sosial untuk membangun Negara. Pemerintah dikembangkan bukan untuk membatasi suatu kekuasaan tetapi untuk menjamin kebebasan kekuasaan. Selain itu, dia juga memberikan gagasan bagaimana membangun masyarakat demokrasi. Tulisan ini diharapkan dapat memberikan pegangan moralitas bagi para politikus.

\section{Abstract}

JJ Rousseau is one of political thinkers. He lives in the advance of science and art. However, he realizes that the progress of science and art declines the moral of society. Democracy, in his view, should be implemented by direct rule without any representation. This is caused by the freedom of every citizens which should be struggled. Everyone has a natural right which could not be seized and be given for others. They make a social contract to shape a nation. A government is developed which is not to limit a power but to ensure the freedom of a power. In addition, he gives an idea on how to build a democratic society. This article is expected to give a moral guidance for politicians.

(C) 2016 Universitas Negeri Semarang

\footnotetext{
Alamat korespondensi:

Jl. Ki Ageng Gribig No. 45, Kedungkandang, Malang Jawa Timur 65139 Indonesia

Email: dayawijaya15@yahoo.com
} ISSN $2477-8060$ 


\section{Pendahuluan}

Masalah moralitas dalam dunia politik dianggap sebagai sesuatu yang kabur. Hal ini terjadi karena begitu banyak yang mengembangkan moral partisan, eksklusif, dan tertutup. Politik dicitrakan sebagai akalakalan dan perebutan kekuasaan saja. Reduksi makna ini jamak terjadi dalam negara demokrasi tak terkecuali Indonesia. Menurut Salahudin (2015: 6), kini rakyat kehilangan daulatnya, ekonomi semakin tidak jelas arahnya, korupsi kian merajalela, dan kaum politisi sibuk mengurus dirinya sendiri dan atau memainkan kartu politiknya untuk kepentingan kaumnya, serta oligarki diamdiam menggeser spirit demokrasi. Sementara, agama yang diharapkan mampu mencerahkan malah tampil sebagai jubah politisi untuk menggoda warga bahwa politik agama itu penting.

Politik uang dalam pemilihan umum baik dari tingkat daerah maupun nasional terus merajalela. Ikon pemilu yang bebas, jujur, dan adil serta merta dipertanyakan oleh khalayak umum. Blum (2013) menjelaskan bahwa negara penganut demokrasi belum tentu menjamin adanya sebuah sistem yang bebas kepentingan. Dia memberikan sebuah contoh bagaimana pasca 1945 pemerintah AS mencoba untuk menggulingkan pemerintahan di lima puluh negara dan campur tangan pada pemilu di negara-negara tersebut. Kemungkinan besar Indonesia masuk dalam negara yang dicampuri tersebut.
Ketidakjujuran serta hukum yang seolah-olah mati suri ini menghasilkan manusia komperador. Manusia komperador cenderung mementingkan kepentingan diri serta golongannya tanpa memperhatikan kepentingan rakyat. Parahnya, perilaku korupsi kini menjadi budaya populer yang jauh akan adanya perasaan malu dan bersalah. Seolah-olah sistem demokrasi yang diterapkan di Indonesia dipengaruhi oleh kepentingan asing. Setidaknya hal ini terlihat dari sikap (kebijakan) pemerintah yang enggan menasionalisasikan beberapa perusahaan asing yang menguasai sektor-sektor yang seharusnya dikuasai negara dan dijalankan oleh pemerintah. Padahal sejatinya para pendiri bangsa menyerukan sosio-demokrasi agar pemerintah dapat menjamin kesejahteraan rakyat (Hariyono, 2013).

Sadar ataupun tidak, kini Indonesia yang disebut sebagai salah satu negara berkembang sedang mengalami proses industrialisasi dari pabrik-pabrik negaranegara maju. Sebagai contoh, penulis memiliki pengalaman untuk berkunjung ke Old Trafford, stadion kebanggaan klub sepak bola liga premier Inggris, Manchester United. Di sekitar stadion terdapat toko resmi klub yang menjual berbagai atribut termasuk kostum klub (jersey), syal, dan berbagai pernak-pernik lainnya. Saat mendekat dan mengamati kostum klub tanpa diduga kostum tersebut made in Indonesia atau dibuat di Indonesia. Nampaknya telah terjadi industrialisasi global disini dimana untuk 
menekan biaya produksi suatu barang dan menekan upah pekerja yang murah maka diputuskan untuk membuat pabrik di negara berkembang. Praktek ini dipandang lebih murah dan hasil produksinya didistribusikan dengan harga yang berkali lipat lebih mahal ke seluruh penjuru dunia. Sebenarnya tidak ada yang menyangsikan bahwa Indonesia memiliki kekayaan yang luar biasa baik dari aspek sumber daya alam maupun sumber daya manusia. Namun, menjadi sebuah renungan mengapa Indonesia belum memenuhi syarat sebagai negara maju padahal demokrasi telah diterapkan sebagai kredo.

Demokrasi ataupun sosio-demokrasi yang diyakini para pendiri bangsa sebagai jalan untuk menyejahterakan rakyat belum begitu sepenuhnya telah dijalankan secara ideal ditengah peta percaturan indutrialisasi yang semakin mengglobal. Hal ini kemudian bermuara pada satu permasalahan dalam demokrasi Indonesia yang masih berproses yakni ketidakpercayaan masyarakat terhadap proses demokrasi dan perpolitikan Indonesia. Dapat dianalogikan bahwa jika kita sebagai anggota dari sebuah organisasi, jika organisasi tersebut memperjuangkan hak-hak serta kepentingan anggotanya maka dapat dipastikan anggotanya akan menunjukkan kinerja serta loyalitas yang bagus pada organisasi tersebut. Begitu pula dengan hubungan negara dan warga negaranya, jika negara mampu mengayomi segala hak-hak dasar warganya maka sikap acuh terhadap negara akan sirna serta rasa nasionalisme akan tumbuh. Inilah karakter utama masyarakat Indonesia kini yang cenderung pragmatis dengan adagium "uang memang bukan segalanya tetapi segalanya butuh uang".

Ketika ilmu politik selalu tunduk pada ranah ilmiah empirik maka yang terlihat hanyalah pertarungan kekuasaan dan kepentingan. Tata politik yang nampak hanyalah kisah-kisah buruk pertikaian seharihari. Perlu kiranya khalayak berfilsafat politik dan merenungkan apa yang sebenarnya terjadi. Berfilsafat politik berarti memandang secara reflektif pergumulan tata hidup manusia sehari-hari (Riyanto, 2011: 39). Salah satu filsuf politik yang layak untuk dibahas adalah Jean-Jacques Rousseau. Pikiran Rousseau telah menjadi inspirasi eksperimen demokrasi bagi para revolusionis Prancis pada akhir abad 18. Dia begitu mengutuk monarki absolut dan masyarakat penindas serta menuntut kembalinya kebebasan manusia. Menurut Rakhmat (2010: xvii), pemikiran Rousseau telah menjadi pemikiran filsafat klasik. Hal ini berarti pemikirannya tersebut relevan untuk berbagai zaman, lintas ruang, dan waktu. Dengan melihat kembali pemikiran filsafat politik Rousseau diharapkan sidang pembaca memiliki gambaran pada makna kebebasan moral dan politik (Haryatmoko, 2014: 15). Tulisan ini akan membahas kehidupan dan pemikiran Rousseau dalam demokrasi meliputi hak dasar manusia; kehendak umum; serta cara membangun masyarakat demokrasi. 


\section{Temuan dan Diskusi}

\section{Kehidupan JJ Rousseau}

Rousseau hadir di muka bumi dibalut dengan kepedihan. Ibunya meninggal sepekan setelah dia dilahirkan. Dia lahir di Jenewa, Swiss pada tanggal 28 Juni 1712. Ayahnya, Issac Rousseau, seorang tukang jam yang menemani masa kecil Rousseau dengan membaca karya klasik Plutarch. Issac merupakan pengagum berat Peradaban Romawi. Dia selalu menggores pikiran Rousseau bahwa kota Romawi kuno adalah cermin dari kehidupan kota yang adil, aman, sejahtera, serta adanya jalinan yang akrab antar anggota masyarakat. Menurut keduanya, Jenewa merupakan representasi kota Romawi kuno yang bahagia. Jenewa adalah kota yang damai dan dikelilingi gunung-gunung serta hutan-hutan yang masih lebat. Keadaan lingkungan ekologinya bersih tanpa polusi. Warga negaranya mematuhi hukum. Baik Rousseau maupun ayahnya bangga menjadi warga kota kecil ini (Suhelmi, 2001: 238239). Pada kemudian hari, Rousseau melihat Jenewa sebagai pemerintahan negara kota yang adil dan demokratis yang pernah ada. Pengagungannya pada negara kota itu menjadi sebab mengapa banyak orang menilai filsafat politiknya tidak pernah ada hubungan langsung dengan politik di masa kini (Sabine, 1981: 227).

Sejak kecil sampai menjelang usia remaja, Rousseau dididik sebagai seorang Calvinis Ortodoks. Namun, dia berganti agama menjadi Katolik karena tiada sarana untuk bertahan hidup dan acara pentahbisannya berlangsung di Turin. Menurut Rousseau dalam Russel (2007: 895), "saya tidak dapat menutup-menutupi bahwa perbuatan suci yang akan saya lakukan pada dasarnya tidak berbeda dengan tindakan seorang bandit". Dia mengakui bahwa apa yang diperbuatnya adalah sesuatu yang salah walaupun dia memeluk Katolik secara tulus. Setelah dia keluar dari Turin dengan membawa uang dua puluh franc, dia menjadi pesuruh seorang wanita bernama Madam de Vercelli. Namun kebersamaan dengan de Vercelli tidak berlangsung lama karena dia meninggal tiga bulan kemudian. Disinilah kemudian Rousseau bertemu dengan Madam de Warens. De Warens kemudian mengangkat Rousseau sebagai anak asuh pada medio 1732. Madam de Warens sangat berjasa membentuk kepribadian dan watak pemikiran Rousseau. Dia menyediakan perpustakaan dan membentuk Rousseau menjadi penulis yang handal (Suhelmi, 2001: 240).

Setelah de Warens menemui ajalnya, Rousseau mulai mengembara dan berjalan kaki tak tentu arah. Dia secara kebetulan menjadi seorang sekretaris pada seorang yang memperkenalkan dirinya sebagai kepala biara ketika mereka berjalan menuju Holy Sepulchre; namun di kesempatan lain Rousseau melakukan hubungan gelap dengan wanita kaya. Wanita tersebut kemungkinan yang menuntunnya untuk menjadi sekretaris bagi duta besar Prancis untuk Venezia bernama Montaigu. Dia mengerjakan tugas 
dari atasannya dengan sangat baik namun dia tidak digaji. Dia kemudian pergi ke Paris untuk mendapatkan keadilan. Dia mendapatkan gajinya yang tertunda serta bertemu dengan Therese le Vasseur. Orang yang kemudian diperlakukan selayaknya seorang istri dan memberikannya lima orang anak (Russel, 2007: 897).

Pada tahun 1749, Rousseau berjalan sambil membaca koran Mercure de France. Dia menemukan iklan sayembara menulis esai dengan pertanyaan, "apakah kemajuan dalam bidang seni dan ilmu-ilmu pengetahuan memberikan sumbangan untuk memurnikan moralitas?". Pertanyaan tersebut membuka mata Rousseau bahwa kegagalan hidupnya yang sebelumnya dia rasakan samar-samar disadarinya dengan terang. Dia menerima tantangan sayembara sebuah akademi di Dijon tersebut dengan respon "tidak!". Dia menguraikan bagaimana sebenarnya kemajuan seni dan ilmu pengetahuan tidak berjalan seiringan dengan moralitas umat manusia. Ternyata dia mendapat hadiah yang pertama dan menjadi terkenal di seantero Prancis (Magnis-Suseno, 1992: 79).

Rousseau mulai menempuh jalan hidup yang sesuai dengan prinsipnya. Dia memilih hidup sederhana dengan menjual arloji. Dia kemudian menulis esai kedua berjudul Discourse on Inequality. Esai tersebut berisi tentang manusia itu baik dan karena institusilah berubah menjadi jahat. Dia kemudian mengirimkan esainya pada Voltaire yang secara terus terang menentang pemikiran
Rousseau. Voltaire merasa Rousseau ingin membawa manusia pada masa kecilnya secara merangkak. Ketika di Lisbon terjadi gempa pada tahun 1755, Voltaire membuat sebuah puisi dan Rousseau menyerangnya, "Voltaire selalu percaya pada Tuhan namun tidak percaya pada siapapun". Pada tahun 1760 -an, Rousseau sangat produktif dengan menerbitkan karyanya seperti La nouvelle Heloise (1760), Emile (1762), dan The Social Contract (1762). Namun kedua buku terakhirnya tersebut yang kemudian menuai kecaman terutama dari pejabat. Pemerintah Prancis, Jenewa, dan Prusia mengusirnya sehingga dia menerima bantuan David Hume untuk ke Inggris pada tahun 1762. Rousseau seperti mengalami gangguan psikologis ditambah dengan kepekaan rasa yang dimilikinya. Dia menuduh Hume akan membunuhnya dan suatu waktu dia memuji Hume sebagai pribadi yang baik. Dualisme perasaan ini kemudian membuatnya melarikan diri ke Paris. Disana dia berada dalam kemiskinan dan diduga meninggal karena bunuh diri (Russel, 2007: 901-902).

Setelah kematiannya, pijar pemikirannya sangat berpengaruh dan diterapkan oleh Robbespierre dalam Revolusi Prancis. Revolusi Prancis sama halnya dengan revolusi di belahan dunia lain sebagai konsekuensi logis dari ketidakmampuan suatu pemerintahan dalam mengelola rakyatnya. Perubahan dalam revolusi Prancis bukan hanya terjadi karena kemelaratan atau penderitaan rakyat tetapi juga karena 
kepentingan golongan yang terdesak atau terancam oleh kesewenangan raja, yakni kaum borjuis. Kaum menengah inilah yang kemudian begitu intens dalam melakukan kritisi pada kinerja Louis XVI dan Maria Antoinette. Hal ini diperparah dengan pemberlakuan pajak yang hanya dibebankan pada kaum tani sedangkan kaum bangsawan dan rohaniawan bebas dari pajak (Romein, 1956: 132-133).

Rasa ingin bebas di kalangan rakyat meningkat seiring dengan tersebar luasnya tulisan JJ Rousseau tentang kontrak sosial dan kedaulatan rakyat. Rousseau berargumen bahwa kebebasan adalah suatu keadaan tidak terdapatnya keinginan manusia untuk menaklukan sesamanya. Manusia merasa bebas dari ketakutan akan kemungkinan terjadinya penaklukan atas dirinya baik secara persuasif maupun kekerasan. Selain itu, dia juga beragumen bahwa manusia bebas adalah manusia yang patuh pada hukum dan peraturan (mematuhi hukum bukan yang membuat hukum) tetapi tidak menjadikan dirinya budak sehingga kebebasan yang dimiliki tidak mengarah pada anarki sosial. Manusia bebas inilah yang kemudian bersepakat untuk membentuk suatu kekuasaan bersama. Kekuasaan bersama inilah yang disebut sebagai kedaulatan rakyat. Tiap individu yang menyerahkan haknya atau kebebasannya tidak kehilangan keduanya tetapi negara yang kemudian bertugas mengayomi setiap individu dalam negara dan jika negara menyimpang dari kehendak umum maka negara akan mengalami krisis (Suhelmi, 2001: 249-252).

\section{Hak Dasar Manusia}

Manusia secara alamiah pada dasarnya memiliki sifat yang baik namun mereka berubah menjadi jahat karena masyarakat. Perang bukanlah bawaan dari alam tetapi karena manusia mengembangkan naluri serakah dan ketinggian hatinya. Hobbes berpendapat keadaan alamiah menjadikan kebebasan manusia sebagai subjek. Mereka cenderung menuntut apa yang seharusnya mereka miliki. Pada posisi tersebut tentunya timbul suatu konflik dimana individu yang lain pasti menginginkan kebebasan yang sama (Nugroho, 2013: 131). Oleh karena itu, kebebasan yang dimiliki setiap manusia akan selalu dibatasi oleh campur tangan orang lain. Berbeda dengan Hobbes, Rousseau berargumen bahwa dalam keadaan alamiah manusia hidup sendiri di tengah hutan yang lebat. Manusia tidak lebih menghasilkan daripada apa yang ia perlukan sendiri. Pada waktu itu tiada hukum alam, seperti yang dikemukakan oleh Locke, sebab tidak perlu aturan bagi orang yang tidak saling memerlukan (Hadiwijono, 1980: 60).

Keadaan alamiah tersebut tidak berlangsung lama karena alam yang ganas menyambut seperti musim panas yang terlalu kering, musim dingin yang berkepanjangan, bencana banjir, atau gempa bumi. Dalam keadaan seperti ini memaksa mereka untuk bekerjasama dengan orang lain. Perubahan 
sosial yang nampak menciptakan tatanan sosial yang baru. Keadaan ini menciptakan persoalan baru karena timbulnya persaingan dan percekcokan. Oleh karena itu, dianggap perlu untuk menciptakan aturan-aturan guna melindungi milik pribadi. Maka pada titik ini muncul hak milik pribadi (Hadiwijono, 1980: 60). Menurut Rousseau, manusia kehilangan hak alamiahnya ketika berada dalam masyarakat sehingga mereka tidak lagi memiliki diri mereka sendiri (Magnis-Suseno, 1992: 80).

Rousseau merasa bahwa manusia lahir di muka bumi ini dengan membawa hak alamiahnya seperti kemerdekaan, kesamaan, dan hak milik. Mereka bahkan rela diperbudak untuk melindungi hak alamiahnya. Kondisi yang tidak masuk akal tersebut telah membawa manusia pada pertentangan dari apa yang seharusnya tidak perlu dipertentangkan. Sikap rela diperbudak ini membawa mereka pada ketenteraman dan perdamaian yang mereka nikmati dalam suatu belenggu. Perbudakan seharusnya menjadi perbuatan yang paling hina malah menimbulkan perdamaian. Perdamaian dalam bingkai dunia tanpa perang menjadi tidak berguna jika mereka melupakan hak manusia yang paling dasar yakni kebebasan. Rousseau merasa bahwa apabila seorang manusia menempatkan dirinya sebagai budak maka dirinya setara dengan binatang yang diperhamba oleh nalurinya. Hal ini tentunya akan menyakitkan hati sang pencipta (Rousseau, 2010: 100-104).
Hak atas harta benda merupakan perjanjian yang diadakan oleh manusia maka setiap orang dapat saja menjual semaunya dengan apa yang dimiliki. Paralel dengan hal tersebut, apabila ada seorang yang menjual kebebasannya (sebagai budak) seperti menjual harta benda maka mereka pada dasarnya telah kehilangan semua hak alamiahnya. Ironisnya para majikan memiliki semua yang dimiliki oleh para budak termasuk anak mereka yang juga berstatus sebagai budak. Padahal setiap anak terlahir bukan sebagai budak tetapi mereka bebas untuk menentukan pilihan hidupnya. Mereka terlahir sebagai manusia dengan seperangkat hak alamiah mereka. Jika lingkaran perbudakan tersebut telah melembaga maka yang terjadi adalah kekuasaan yang sewenang-wenang dan terlegitimasinya hukum yang paling kuat yakni hukum yang paling berkuasa (Rousseau, 2010: 106).

Rousseau menginginkan kehidupan yang seimbang serta kebebasan yang nyata di dalam komunitas sederhana. Masyarakat seperti itu menurutnya tercipta dari kontrak sosial. Kontrak tersebut bukan bertujuan untuk membatasi namun menciptakan kebebasan dalam bentuk tertinggi (Fink, 2013: 78-79). Kedaulatan rakyat harus ditegakkan agar manusia dalam masyarakat dan negara tidak terasing. Kedaulatan rakyat bermakna suatu pemerintahan diselenggarakan oleh rakyat dan bertanggung jawab pada rakyat. Dengan kedaulatan ini berarti rakyat menjalankan suatu pemerintahan dengan satu 
kehendak umum. Walaupun setiap rakyat memiliki pemikiran yang berbeda namun selama perbedaan tersebut membawa mereka pada kepentingan bersama maka kehendak rakyat itulah yang disebut Rousseau sebagai basis bagi konstruksi negara dan undangundang (Nugroho, 2013: 132).

Manusia harus menjadi warga negara terlebih dahulu sebelum dia menjadi seseorang dengan segala haknya. Pemerintah memiliki tugas memberikan setiap warga negaranya kemerdekaan dibawah jaminan hukum, menjamin kesejahteraan material, dan menghilangkan ketidakadilan dalam pembagian kekayaan negara, dan harus membuat sistem pendidikan yang benar-benar membebaskan anak. Akhirnya manusia bukan lagi hanya memiliki status politik tetapi juga status sosial "seseorang" dengan hak kesetaraan (Sabine, 1981: 231-235). Menurut Fink (2013: 81), kesetaraan bagi Rousseau bukan hanya bagi yang kaya dan terpelajar, seperti pandangan Locke, tetapi juga bagi kaum miskin dan bodoh. Walaupun tidak menawarkan solusi yang nyata, Rousseau beranggapan adalah hal yang wajar apabila ada bagian minoritas yang dikesampingkan dari politik.

\section{Kehendak Umum}

Rousseau beranggapan bahwa kebebasan akan terjadi apabila rakyat yang memimpin dirinya sendiri. Namun apakah mungkin rakyat memiliki satu suara dan mau untuk bersatu? Rousseau menjelaskannya dengan kehendak umum. Kehendak umum berbeda dengan kehendak semua rakyat. Kehendak umum ditujukan pada kepentingan umum dan dapat bersifat memaksa apabila terdapat suatu perjanjian sosial. Kehendak umum adalah basis bagi konstruksi negara Rousseau. Undang-undang harus merupakan ungkapan kehendak umum. Tidak ada perwakilan rakyat karena kehendak rakyat tidak dapat diwakili. Rakyat sendiri harus berkumpul dan menyatakan kehendaknya melalui perundangan yang diputuskan. Pemerintah yang kemudian melaksanakan keputusan tersebut. Jika rakyat yang memerintah sendiri dan secara langsung maka tidak diperlukan lagi undang-undang dasar atau konstitusi karena yang dikehendaki rakyat adalah hukum (Magnis-Suseno, 1992: 81).

Hukum adalah ekspresi dari kehendak umum dan ada untuk menjamin kepentingan umum. Rousseau berpendapat bahwa semua orang harus berpendapat dalam menyusun suatu hukum, undang-undang, atau pemimpin. Hal ini akan masuk akal apabila mengikuti pola pikir teorema juri dari Marquis de Condorcet. Simpson (2006: 73) menjelaskan bahwa:

"groups make better decisions than individuals and large groups make better decisions than small ones. To put it a little more technically, the theorem shows that if voters are deciding an issue with one right and one wrong answer, and if the average probability that each voter will choose the right answer is 
above, then the probability that a majority will choose the right answer increases toward 1 as the number of voters increases. It may take the reader a moment to grasp the point; but as soon as one does, many striking things can be seen to follow. The most important consequence of the theorem is that the procedure of majority-rule can produce decisions that are better than the average competence of the voters involved; in fact, it can even yield decisions that are better than those of the most competent voter taken by herself. This means that, within the limiting conditions of the theorem, the majority judgment of a middling group is more likely to be correct than the judgment of the wisest individual"

Kehendak umum, mengikuti teorema juri, berada pada hal yang benar karena mengarah pada kepentingan bersama.

Namun, akan sangat berbahaya apabila kepentingan tertentu berada dibalik kepentingan umum, berhasil membuat suatu aturan. Keputusan tersebut akan membawa negara pada kesewenangan. Tidak ada sebenarnya pemerintahan demokrasi yang hadir di muka bumi karena tidak dapat dibayangkan bagaimana seseorang sangat konsisten pada kepentingan umum. Di sisi yang lain, para legislatif mewakilkan kepentingan umum pada para eksekutif yang juga belum tentu melaksanakan tugasnya secara konsekuen. Jika memang ada negara para dewa maka mereka akan memerintah dengan demokratis. Pemerintahan yang sempurna tidaklah cocok dengan manusia (Green, 1955: 296).

Memang pada dasarnya tidak ada manusia yang sempurna tetapi menuju kesempurnaan kiranya menjadi tujuan bersama. Demikian pula yang diinginkan para pendiri bangsa ketika mereka menyusun konstitusi. Menurut Rousseau (2010: 47-51), para pendiri bangsa (legislator) adalah orang yang luar biasa karena mereka bukan sebagai seorang anggota dewan atau penguasa berdaulat tetapi seorang pendiri republik. Walaupun demikian mereka tidak menyusun undang-undang sesuai dengan idealisme mereka namun lebih berpijak pada rakyat. Mereka menguji terlebih dahulu apakah rakyat yang akan menerimanya memang sanggup menanggungnya. Mereka harus memastikan bahwa rakyat telah berada dalam kondisi yang sesuai dalam undang-undang.

Salah satu contoh, pada pasal 28E UUD 1945 (konstitusi Indonesia) dijelaskan bahwa setiap orang berhak memilih kewarganegaraannya. Hal ini dapat dipahami bahwa seseorang berhak memilih untuk menjadi warga negara Indonesia atau warga negara asing. Jika mereka memilih menjadi warga negara asing maka mereka tidak dapat menjadi bagian dari Negara Kesatuan Republik Indonesia walaupun mereka lahir dan besar di Indonesia. Wacana pemberitaan tentang dwikewarganegaraan mulai marak kini. Para diaspora Indonesia mengajukan petisi pada DPR untuk mengakui keberadaan mereka dengan mengesahkan UU 
dwikewaganegaraan. Jika mengikuti pola berpikir Rousseau, mereka yang mengajukan petisi tersebut adalah para pembangkang. Para legislatif harus tegas dalam menindak hal ini. Jika hal ini dibiarkan maka keberadaan negara akan melemah dan berbagai visi partisan akan terus merasuk di tubuh rakyat.

Rousseau (2010: 40-41) menjelaskan konstitusi atau undang-undang dasar yang disetujui dalam pakta sosial harus dipatuhi oleh seluruh warga negara. Oleh karena itu, apabila hukuman mati dijatuhkan pada seorang warga negara karena membunuh warga yang lain maka hukuman tersebut merupakan konsekuensi yang harus diterima. Ketika dia melanggar konstitusi berarti dia menjadi pembangkang dan pengkhianat tanah air. Dia berhenti sebagai anggota masyarakat dan menyatakan perang dengan masyarakat. Kelangsungan dirinya tidak lagi sejalan dengan visi dan misi dari negara sehingga salah satu dari keduanya harus dimatikan salah satu, negara yang dibubarkan atau warga negara yang keluar dari negara tersebut. Negara harus bertindak dengan tegas dalam menindak para pembangkang. Negara lemah akan menuai besarnya jumlah kejahatan demikian pula sebaliknya jika negara kuat maka jumlah kejahatan akan semakin sendikit.

Konstitusi sebuah negara berisi pedoman dalam kehidupan berbangsa dan bernegara termasuk pemerintahan. Pemerintah bukan dibentuk melalui suatu kontrak sosial namun pemilihannya didasarkan pada aturan yang termaktub dalam undang-undang. Jika konstitusi berpijak pada kehendak umum maka pemerintah dibentuk oleh rakyat. Rakyat yang mengangkat para pemimpin yang akan ditugasi melaksanakan tugas-tugas pemerintahan. Para pelaksana eksekutif sama sekali bukan majikan rakyat melainkan petugasnya. Rakyat dapat mengangkat dan memberhentikan mereka sesuka hati. Mereka sama sekali tidak membuat kontrak tetapi mematuhi. Dengan melakukan tugas yang diwajibkan negara kepada mereka, mereka hanya memenuhi kewajiban sebagai warga negara tanpa berhak sedikitpun untuk memperdebatkan persyaratannya (Rousseau, 2010: 103-105).

Menurut Rousseau (2010: 110-101), kehendak umum tidak dapat dihancurkan. Ketika seorang warga negara keuntungan umum demi kepentingan pribadi, dia akan menyadari bahwa sebenarnya dia tidak memadamkan kepentingan umum tetapi membelokkannya. Pada titik ini, kehendak umum dibawahi oleh kehendak lain yang membawahinya. Selama setiap warga negara memiliki hak berpendapat maka kehendak umum selalu konstan, tidak berubah, dan murni. Hak berpendapat tidak dapat dicabut dari warga negara. Aktivitas berpendapat, berbagi, dan berdiskusi merupakan nyawa dari keberlangsungan kehendak umum.

\section{Membangun Masyarakat Demokrasi}

Rousseau (2010: 74-76) menyatakan bahwa demokrasi adalah suatu sistem dimana kehendak umum menjadi kepentingan 
bersama. Kehendak umum selalu benar. Kehendak umum adalah representasi dari semua pendapat warga. Oleh karena itu, kehendak umum selalu berada di jalan yang benar. Rousseau berpendapat demokrasi paling tepat diterapkan di negara kecil, aristokrasi di negara menengah, dan monarki di negara-negara besar. Apa yang kita sebut sekarang sebagai demokrasi menurut Rousseau sebagai aristokrasi elektif dimana terdapat pemerintahan yang mewakili rakyat. Dengan demikian Indonesia sebagai negara besar perlu berpijak pada kehendak umum. Apa yang menjadi kepentingan umum itulah yang harus diusahakan oleh pemerintah. Dalam kondisi seperti ini menjadi urgen untuk segera membangun masyarakat demokrasi. Pada konteks ini, demokrasi yang dimaksud adalah tata kelola masyarakat yang mengarah pada kepentingan umum.

Baswedan (2015: 113) mengungkapkan bahwa membangun demokrasi berarti melakukan modernisasi pada kultur politik (kesadaran kolektif) suatu bangsa. Perubahan yang mendadak tentu sulit dilakukan pada masyarakat Indonesia. Oleh karena itu, upaya pembangunan masyarakat demokrasi perlu dilakukan dari internalisasi nilai-nilai demokrasi sejak manusia lahir dan tumbuh di lingkungan keluarga. Gagasan tersebut awalnya diungkapkan oleh John Locke dan kemudian dilanjutkan oleh Rousseau.

Locke berkeyakinan bahwa manusia lahir seperti kertas kosong sehingga orang disekitarnya yang menggores pengetahuan mereka. Mereka akan berpikir seperti apa yang mereka alami. Mereka akan berpikir demokratis hanya jika berada dalam kehidupan keluarga yang demokratis. Orang tua memiliki beberapa pedoman dan aturan yang bertujuan untuk menjaga, merawat, dan mendidik anak-anaknya. Hal ini dilakukan agar anaknya mendapatkan cara berpikir yang baik dan kedewasaannya (Locke, 1691: 241). Setelah anak dapat berpikir secara rasional, maka diantara orang tua dan anak akan memiliki tugas yang sama yakni tugas orang tua adalah membesarkan anak dan si anak memiliki tugas menghormati orang tuanya. Hal ini diperlukan untuk saling memahami tugas dan dibuat sebuah kesepakatan secara alamiah diantara mereka.

Dalam fase berikutnya mereka siap untuk memasuki dunia masyarakat. Mereka akan menyesuaikan diri dengan aturan yang sama dalam satu komunitas berdasarkan apa yang mereka alami dalam pendidikan keluarga. Aturan-aturan di masyarakat pada hakikatnya berjalan secara alami pada sistem pemerintahan seperti yang mereka alami saat masih kanak-kanak. Jika orang tua mereka mendidik dengan kebebasan dan kesetaraan maka mereka akan berusaha mendapatkan kebebasan dan kesetaraan itu sendiri. Oleh karena itu, ketika mereka memasuki dunia masyarakat; masyarakat demokrasi akan muncul dan mereka secara natural akan membangun pemerintahan yang demokratis.

Seperti halnya Locke, dengan seruan kembali ke alam Rousseau mengembangkan 
kecenderungan pemikiran romantis yang dimulai dari pemujaan masa kecil dan kebaikan alam; pemujaan masyarakat biasa; dan pemujaan pada demokrasi sebagai kehendak umum (Gairdner, 1999: 88). Dia seakan-akan ingin mengajak manusia kembali pada keadaan alamiah dan merangkak kembali ke masa kecilnya yang dianggap sebagai struktur manusia yang ideal. Pendidikan menurutnya adalah pembebasan manusia karena belenggu masyarakat. Ketika kebebasan diraih dia dapat mengemukakan pendapatnya secara bebas. Hal ini akan membawa manusia pada kehidupan politik yang dicitakannya yakni kehendak umum sebagai prasyarat demokrasi Rousseau.

Gagasan dasarnya dalam Emile (karya Rousseu tentang Pendidikan) adalah "ketika keluar dari tangan sang Pencipta semua baik, namun menjadi rusak di tangan manusia". Prinsip pendidikan Rousseau didasarkan atas falsafah hidupnya dan kebenciannya pada peradaban manusia. Pertama, Emile dijauhkan dari pengaruh buruk peradaban manusia. Ia dibesarkan di pedesaan, jauh dari keluarga, masyarakat, dan buku-buku. Ia dibiarkan bebas untuk belajar dari pengalaman sendiri karena alam adalah guru terbaik. Rousseau lebih mementingkan pembinaan moral (kejujuran dan kebenaran) dan kualitas perasaan. Walaupun Emile dibesarkan jauh dari masyarakat, pada suatu waktu ia akan menjadi kepala keluarga dan warga kota. Maka tahun-tahun terakhir hidupnya digunakan untuk mempersiapkannya keperluan tersebut (Rousseau, 1762).

Pendidikan Emile disesuaikan secara alami dengan perkembangan usianya. Pada usia dini dia tidak perlu terlalu banyak diajari agama atau nilai-nilai moral. Untuk pembinaan intelektualnya dilakukan dengan pembinaan kepekaan perasaan. Metode yang paling baik adalah observasi langsung, sama sekali bukan melalui penalaran ataupun melalui buku-buku. Dia belajar dengan melakukan kontak langsung dengan bendabenda, kenyataan sosial, mata pencaharian dan lain-lain. Observasi langsung ini berarti bahwa dia belajar sendiri secara aktif. Pembimbing (guru atau tutor) harus menguasai cara untuk menggugah rasa ingin tahu si anak, dan menghindarkannya dari perilaku buruk yang timbul dalam kehidupan bermasyarakat seperti kesombongan, dusta, serta keinginan untuk menguasai (Rousseau, 1762).

Sistem pendidikan yang ditawarkan Rousseau mencoba merencanakan pendidikan seperti apa yang seharusnya diterapkan pada setiap jenjang kehidupan manusia. Secara tidak langsung tentunya membahas model pendidikan bagi tahapan perkembangan manusia. Karya Rousseau tersebut terbagi menjadi lima bagian: pertama dan kedua berisi tentang pendidikan yang ditujukan pada manusia sampai umur 12 tahun; bagian ketiga dan keempat menjelaskan transisi manusia kearah kedewasaan; dan bagian terakhir menjelaskan umur kebijaksaan manusia mulai 
dari umur 20 hingga 25, pada masa ini manusia akan diikuti oleh kebahagiaan tetapi Rousseu sayangnya tidak menjelaskan akhir dari perkembangan manusia yang lebih dewasa antara umur 25 hingga seterusnya (Rousseau, 1762).

\section{Demokrasi Indonesia dalam Perspektif} Rousseau

Angin reformasi mewarnai perubahan kehidupan politik Indonesia pasca keruntuhan Soeharto. Berbagai pihak mulai menyuarakan jalan kemanusiaan dan mengembalikan manusia pada martabatnya. Mereka mulai menyerukan berbagai pembenahan yang harus dilakukan pemerintah termasuk penegakan hukum. Namun, pemerintah tidak sepenuhnya berpegang pada rakyat walaupun memakai kredo demokrasi. Mereka lebih berpihak pada pasar. Salah satu intrik politik nasional yang mengemuka adalah terbunuhnya pejuang HAM (Hak Asasi Manusia), Munir Said Thalib. Dia menjadi tumbal sistem plutokrasi yang berjalan dalam perpolitikan Indonesia. Munir dibunuh dengan menggunakan racun arsenik yang dicampur ke dalam minumannya saat terbang dari Jakarta menuju Amsterdam,

7 September 2004. Pembunuhan tersebut sampai kini belum tuntas dan otak dibalik pembunuhan tersebut belum terungkap. Tim Pencari Fakta (TPF) menjelaskan bahwa kasus Munir adalah pembunuhan berencana dengan berbagai kalangan yang terlibat dalam konspirasi pembunuhan Munir (Kompas, 7 September 2015).
Ironisnya, hukum yang ditegakkan terbentur tembok kekuasaan. Hukum yang ada seolah mengikuti apa yang diinginkan penguasa. Bahkan, Pollycarpus Budihari Priyanto (pelaku lapangan) mendapatkan kebebasan bersyarat dari pemerintah. Setiap warga negara tentunya berhak mendapatkan keadilan serta untuk tahu agar tidak terulang pembunuhan politik keji seperti yang menimpa Munir (Kompas, 7 September 2015). Effendi \& Evandri (2010: 63-65) menjelaskan bahwa watak hukum yang dihasilkan dalam sistem politik demokratis bersifat responsif dan akomodatif. Substansi hukum yang tertuang di dalam beragam peraturan perundangan yang ada menghormati dan menjunjung tinggi HAM. HAM menjadi salah satu ukuran penegakan hukum. Persoalan HAM hendaknya mendapat perhatian pemerintah dalam arti luas, pimpinan eksekutif, legislatif, dan yudisial mampu dan mau menerjemahkan kehendak rakyat sehingga jeritan rakyat menjadi perhatian utama.

Demokrasi Rousseau bukanlah bersifat demagogi yang berkedok demokrasi tetapi merupakan representasi dari kehendak umum. Setiap pemegang kekuasaan harus berkiblat pada kehendak umum bukan berpijak pada mayoritas apalagi penguasa pasar. Seyogyanya pemerintah mulai melihat tujuan bersama dalam kehendak umum yang disuarakan oleh rakyat. Kehendak umum menginginkan adanya kejelasan kasus Munir bukan pengalihan isu yang berujung pada 
pengabaian peradilan kasus Munir. Menurut Rousseau dalam Fink (2013: 81), setiap warga negara berhak mendapatkan kesetaraan termasuk hukum. Setiap warga berhak mendapatkan keadilan termasuk keluarga korban pelanggaran HAM. Istri Munir, Suciwati, terus berupaya mendapatkan haknya untuk mengetahui dalang dibalik pembunuhan Munir. Kekuasaan yudikatif seharusnya berlaku adil dalam melihat hal ini. Mereka harus mendengarkan kehendak umum dan mengabaikan kepentingan kelompok tertentu. HAM seharusnya bukan menjadi milik elit tertentu tetapi seharusnya juga menjadi miliki setiap manusia dengan status sosial yang meraka sandang. Rousseau dalam Fink (2013:81) berpendapat bahwa kaum miskin dan bodoh juga berhak untuk mendapatkan keadilan.

Nilai-nilai kesetaraan HAM sudah sewajarnya diinternalisasikan dalam diri manusia. Rousseau merasa pendidikan HAM bukan diberikan pada siswa dengan paksaan tetapi disesuaikan dengan perkembangan usianya. Dia memberikan contoh pada usia dini, anak-anak tidak perlu dijejali dengan dogma-dogma agama tetapi diberikan pembinaan kepekaan perasaan dengan pengamatan langsung. Hal ini juga yang dilakukan oleh tim Omah Munir (Kompas, 7 September 2015). Mereka aktif untuk menyuarakan HAM pada khalayak terutama generasi muda (program "melawan lupa"). Mereka mengadakan uji coba (piloting) simulasi pengayaan HAM pada mata pelajaran Pendidikan Pancasila dan Kewarganegaraan (PPKn) di sejumlah sekolah menengah pertama (SMP). Mereka membuat modul khusus HAM yang diluncurkan beberapa waktu lalu di Bogor dan Malang. Modul tersebut dinilai mampu untuk membangkitkan rasa ingin tahu tentang HAM. Mereka belajar HAM sambil bermain dengan bantuan beberapa hal seperti alat bantu simulasi (topeng Munir, Marsinah, dan Udin), kartu sejarah HAM, dan bahan untuk drama. Dengan mempelajari HAM melalui permainan drama misalnya, anak-anak akan memahami secara konkret kasus pelanggaran HAM dengan dampak yang mereka terima dan rasakan.

\section{Kesimpulan}

Demokrasi Rousseau tidak terlepas dari teori sentralnya pada kebebasan dan kehendak umum. Demokrasi sebagai tata kelola rakyat selalu berbasis pada kebebasan dan kehendak umum. Bila bagi Locke pemerintahan yang baik seharusnya dipisahkan menjadi tiga yakni legislatif, eksekutif, dan federatif; pemerintahan yang baik bagi Rousseau tidak perlu dibagi karena dapat memecah keutuhan negara. Dia beranggapan bahwa demokrasi yang ideal tidak akan pernah ada karena sangat kecil kemungkinan manusia memperjuangkan kepentingan umum. Namun, dia juga berpendapat kepentingan umum pasti selalu ada walaupun dibayangi oleh kepentingan pribadi. Selama kebebasan berpendapat 
dijunjung tinggi dalam kehidupan politik dan musyararah dalam merancang kebijakan dilakukan, maka pemerintahan telah mengarah pada demokrasi idealnya Rousseau. Ketika kehendak umum selalu dikedepankan maka kesetaraan, keadilan, dan kesejahteraan rakyat secara tidak langsung akan tergapai.

\section{Daftar Pustaka}

Baswedan, A. R. (2015). Merawat tenun kebangsaan: refleksi ihwal kepemimpinan, demokrasi, dan pendidikan.

Blum, W. (2013). Demokrasi: Ekspor Amerika Paling Mematikan. Jakarta: Bintang Belia.

Effendi, AM \& TS. Evandri. (2010). HAM dalam Dinamika/Dimensi Hukum, Politik, Ekonomi, dan Sosial. Penerbit Ghalia Indonesia.

Fink, H. (2003). Filsafat Sosial: Dari Feodalisme hingga Pasar Bebas.

Gairdner, W. (1999). Jean-Jacques Rousseau and the romantic roots of modern democracy. Humanitas, 12 (1), 77.

Green, F. C. (1955). Jean-Jacques Rousseau a Critical Study of His Life and Writings.

Hadiwijono, H. (1980). Sari sejarah filsafat barat. Kanisius.

Hariyono. (2013). Arsitektur Demokrasi Indonesia. Malang: Setara Press

Haryatmoko, J. (2003). Etika politik dan kekuasaan. Kompas.
Kasus Munir Masih Tetap Misterius. Kompas,

7 September 2015, Hal.3

Konsep HAM Masih Elitis. Kompas, 7 September 2015, Hal.3

Locke, J. (1727). The Works of John Locke (Vol. 2). A. Bettesworth.

Magnis-Suseno, F. (1992). Filsafat sebagai ilmu kritis. Penerbit Kanisius.

Nugroho, B. (2013). “Jean-Jacques Rousseau: Dualisme Konsep Manusia sebagai Pelaku Kontrak Sosial”. B. Suyanto (Ed). (2013). Filsafat Sosial. Malang: Aditya Media Publishing

Rakhmat, J. (2010). "Ketimpangan dan Agama Madani: Belajar dari Rousseau". Prakata dalam JJ Rousseau. (2010). Perihal Kontrak Sosial atau Prinsip Hukum-Politik. Jakarta: Dian Rakyat

Riyanto, E. A. (2011). Berfilsafat politik. Penerbit Kanisius.

Romein, J. (1956). Aera-Eropa: Peradaban Sebagai Penyimpangan dari Pola Umum. Bandung-JakartaAmsterdam: PT Ganaco.

Rousseau, J. J. (1964). Discourse on the Origin and Foundations of Inequality Among Man. J.-J. Rousseau, The First and Second Discourses. RD Masters, ed. New York: St. Martins Press.

Rousseau, J. J. (2010). Perihal kontrak sosial atau prinsip hukum politik. Dian Rakyat, Forum Jakarta-Paris dan Universitas Padjajaran. 
Rousseau, J. J. (1979). Emile or on education (A. Bloom, Trans.). New York: Basic.(Originally published 1762).

Russell, B. (2004). Sejarah Filsafat Barat: Kaitannya Dengan Kondisi Sosiopolitik Zaman Kuno Hingga Sekarang, terj. Sigit Jatmiko dkk. Yogyakarta: Pustaka Pelajar.

Sabine, G. H. (1964). Teori-teori politik: sejarah pertumbuhan dan perkembang annya. Binacipta.

Salahudin, A. 4 Juli 2015. Moralitas Politik. Kompas. Hal. 6

Simpson, M. (2006). Rousseau's theory of freedom. A\&C Black.

Suhelmi, A. (2001). Pemikiran Politik Barat: Kajian Sejarah Perkembangan Pemikiran Negara. Masyarakat dan Kekuasaan., Jakarta: Gramedia. 